Chapman University

Chapman University Digital Commons

Food Science Faculty Articles and Research

Science and Technology Faculty Articles and

Research

9-6-2018

\title{
Concentration of Listeria monocytogenes in Skim Milk and Soft Cheese through Microplate Immunocapture
}

Steven A. Rogers

Chapman University

Melissa Calicchia

Food Microbiological Laboratories, Inc.

Rosalee S. Hellberg

Chapman University, hellberg@chapman.edu

Follow this and additional works at: https://digitalcommons.chapman.edu/food_science_articles

Part of the Food Biotechnology Commons, Food Microbiology Commons, Food Processing Commons, and the Other Food Science Commons

\section{Recommended Citation}

Rogers, S. A., Calicchia, M. \& Hellberg, R. S. (2018). Concentration of Listeria monocytogenes in skim milk and soft cheese through microplate immunocapture. Journal of Microbiological Methods, 153, 54-59. doi: 10.1016/j.mimet.2018.09.005

This Article is brought to you for free and open access by the Science and Technology Faculty Articles and Research at Chapman University Digital Commons. It has been accepted for inclusion in Food Science Faculty Articles and Research by an authorized administrator of Chapman University

Digital Commons. For more information, please contact laughtin@chapman.edu. 


\section{Concentration of Listeria monocytogenes in Skim Milk and Soft Cheese through Microplate Immunocapture}

\section{Comments}

NOTICE: this is the author's version of a work that was accepted for publication in Journal of Microbiological Methods. Changes resulting from the publishing process, such as peer review, editing, corrections, structural formatting, and other quality control mechanisms may not be reflected in this document. Changes may have been made to this work since it was submitted for publication. A definitive version was subsequently published in Journal of Microbiological Methods, volume 153, in 2018. DOI: 10.1016/j.mimet.2018.09.005

The Creative Commons license below applies only to this version of the article.

\section{Creative Commons License}

\section{(c) 1 (1) 90}

This work is licensed under a Creative Commons Attribution-Noncommercial-No Derivative Works 4.0 License.

\section{Copyright}

Elsevier 
1 Concentration of Listeria monocytogenes in Skim Milk and Soft Cheese through Microplate

\section{Immunocapture}

3

4 Authors: Steven A. Rogers ${ }^{\mathrm{a}}$, Melissa Calicchiab ${ }^{\mathrm{b}}$, and Rosalee S. Hellberga*

6 a Chapman University, Schmid College of Science and Technology, Food Science Program, One

7 University Drive, Orange, CA USA 92866

$8 \quad{ }^{b}$ Food Microbiological Laboratories, Inc., 10653 Progress Way, Cypress, CA USA 90630

9

$13 *^{*}$ Corresponding Author:

14 Rosalee S. Hellberg

15 Ph: 714-628-2811

16 E-mail: hellberg@chapman.edu

17

18 Declarations of interest: none

19

20 


\section{ABSTRACT}

22 Microplate immunocapture is an inexpensive method for the concentration of foodborne

23 pathogens using an antibody-coated microplate. The objective of this study was to determine the

24 efficacy of microplate immunocapture as an alternative to traditional enrichment for

25 concentrating Listeria monocytogenes to levels detectable with selective plating or real-time

26 PCR. L. monocytogenes isolates serologically characterized as Type 1 (1/2a) and Type 4

27 (untypeable) were grown overnight and diluted to $10^{0}$ to $10^{6}$ colony-forming units (CFU)/mL.

28 The isolates were used to optimize microplate immunocapture in tryptic soy broth with $0.6 \%$

29 yeast extract (TSBYE), skim milk, and queso fresco samples. Following microplate

30 immunocapture, the bacteria were streaked onto polymyxin-acriflavine-LiCl-ceftazidime-

31 aesculin-mannitol (PALCAM) agar, followed by incubation at $37^{\circ} \mathrm{C}$ for $24 \pm 2 \mathrm{~h}$. The bacteria

32 also underwent real-time polymerase chain reaction (PCR). The optimized microplate

33 immunocapture method was tested in triplicate for its ability to capture L. monocytogenes in

34 broth and food samples. Overall recovery rates for L. monocytogenes in food samples at cell

35 populations of $10^{0}, 10^{2}$, and $10^{4} \mathrm{CFU} / 25 \mathrm{~g}$ using microplate immunocapture with real-time PCR

36 were $88.9 \%, 94.4 \%$, and 100\%, respectively. Recovery in these matrices using microplate

37 immunocapture with selective plating was comparatively lower, at $0 \%$, 44.4\%, and 100\%,

38 respectively. Conventional culture method showed 100\% detection at each inoculation level.

39 Microplate immunocapture combined with real-time PCR shows high potential to reduce the

40 time required for detection, with concentration of $L$. monocytogenes to detectable levels within

41 1-4 h. The incorporation of a short enrichment step may improve recovery rates at low cell

42 levels.

43 Keywords: Microplate immunocapture; cheese; milk; real-time PCR; Listeria monocytogenes 


\section{Introduction}

Listeria monocytogenes is a facultative anaerobic bacterium that is especially problematic

46 due to its ability to survive and grow at refrigerated conditions (FDA, 2012). This pathogen has

47 the highest hospitalization rate (94.0\%) and the third-highest death rate (15.9\%) among

48 foodborne pathogens in the United States (Scallan et al., 2011). Common symptoms caused by $L$.

49 monocytogenes are fever, muscle aches, nausea, and vomiting (FDA, 2012). However, in more

50 serious cases it can cause septicemia and meningitis, as well as induce stillbirth or miscarriage in

51 pregnant women. Listeriosis is often linked to raw or ready-to-eat foods, such as fresh produce,

52 unpasteurized milk, smoked fish, and deli meats. There are 13 known serotypes of $L$.

53 monocytogenes, with strains of serotypes $1 / 2 \mathrm{a}, 1 / 2 \mathrm{~b}$, and $4 \mathrm{~b}$ responsible for the majority of

54 foodborne infections. The U.S. Food and Drug Administration (FDA) has a zero-tolerance policy

55 for L. monocytogenes in ready-to-eat foods and it is consistently one of the most common

56 pathogens associated with food recalls in the United States (FDA, 2018).

57 Dairy products, such as milk and cheeses, are a major cause of outbreaks linked to $L$.

58 monocytogenes (CDC, 2017). For example, L. monocytogenes was among the top three

59 pathogens linked to 90 foodborne outbreaks associated with cheese in the United States from

601998 to 2011 and it was associated with 5 of the 6 deaths reported (Gould, Mungai, \&

61 Behravesh, 2014). Mexican-style cheese, including queso fresco, was the main type of cheese

62 associated with illness from L. monocytogenes during this time period (Gould et al., 2014).

63 Queso fresco is a soft, unaged cheese that is susceptible to Listeria survival and growth due to its

64 relatively high moisture content and low acidity (Moreno-Enriquez et al., 2007).

65 Cultural methods for the isolation of L. monocytogenes involve a series of pre-enrichment

66 and enrichment steps, followed by plating on selective/differential agar (Hitchens, Jinneman, \& 
67 Chen, 2016). This process is very time-consuming, usually requiring 2-4 days, not including the

68 time required for confirmation of isolated colonies. Bacterial separation and concentration

69 methods have the potential to reduce or possibly eliminate the need for pre-enrichment and

70 enrichment steps, thereby significantly shortening the time required for isolation (Stevens \&

71 Jaykus, 2004). These techniques are also advantageous because they can be combined with rapid

72 detection methods, such as polymerase chain reaction (PCR) or enzyme-linked immunosorbent

73 assay (ELISA), further reducing the time to detection.

Immunomagnetic separation is a widely used method for bacterial separation and

75 concentration; however, it is relatively expensive due to the need for antibody-coated beads

76 (Amagliani et al., 2006; Chen et al., 2017; Ma et al., 2014). Non-magnetic immunocapture is an

77 inexpensive alternative that relies on the binding of antibodies to a solid plastic support (Arbault,

78 Desroche, \& Larose, 2014). This technique has been successfully used for the concentration of

79 foodborne pathogens in a limited number of studies (Arbault, Larose, Desroche, \& Nexidia,

80 2014; Fakruddin, Hossain, \& Ahmed, 2017; Molloy, Brydon, Porter, \& Harris, 1995). For

81 example, Arbault et al. (2014) were able to concentrate Escherichia coli O157:H7 from ground

82 meat and raw milk cheese samples with an antibody-coated microplate. Using a combination of

83 the microplate and a subculture step (3-5 h), E. coli was recovered at levels of $10^{5} \mathrm{CFU}$ as

84 compared to $10^{3}-10^{4} \mathrm{CFU}$ with magnetic beads. In another study, microplate immunocapture

85 was evaluated as a potential method for the concentration of Vibrio cholera, Salmonella enterica

86 serovar Typhi, and Shigella flexneri from a variety of food samples (Fakruddin et al., 2017).

87 Overall, the authors found that microplate immunocapture combined with PCR or selective

88 plating allowed for improved recovery of the target pathogens from foods as compared to

89 traditional culture methods. 
PCR is a well-established technique for the rapid identification of foodborne pathogens

91 and it is widely recognized for its specificity and sensitivity (Zhao, Lin, Wang, \& Oh, 2014).

92 Real-time PCR is advantageous over traditional PCR because it enables continuous monitoring

93 of the results as the reaction proceeds and eliminates the need for post-PCR processing steps.

94 There are numerous commercially available kits for the detection of L. monocytogenes using

95 real-time PCR (Law, Ab Mutalib, Chan, \& Lee, 2015) and a real-time PCR assay for detection of

96 L. monocytogenes has been published in the FDA's Bacteriological Analytical Method (BAM)

97 (FDA, 2015). Although PCR-based methods are susceptible to inhibition from compounds in the

98 food matrix, concentration methods such as microplate immunocapture can help to overcome

99 this by separating the target organism from the rest of the sample (Fakruddin et al., 2017;

100 Stevens \& Jaykus, 2004).

101 The specific aims of this study were to: (1) determine the ability of microplate

102 immunocapture combined with selective plating or real-time PCR to detect L. monocytogenes in

103 a pure broth solution within 1 workday (8 h), (2) optimize microplate immunocapture as a means

104 of concentrating L. monocytogenes in milk and cheese samples for subsequent detection with

105 selective plating or real-time PCR, and (3) determine the sensitivity and time to detection for

106 microplate immunocapture combined with selective plating or real-time PCR.

\section{2. Materials and methods}

$108 \quad 2.1$ Media and bacterial strains

109 All media were obtained from Becton, Dickinson and Company [(BD) (Franklin Lakes,

110 NJ)] unless otherwise stated. Two environmental isolates of L. monocytogenes were obtained

111 from the U.S. Food and Drug Administration (FDA) Pacific Regional Laboratory Southwest

112 (Irvine, CA). The isolates were serologically categorized as Type 1 (T1; serotype 1/2a) and Type 
1134 (T4; untypeable) by a combination of slide agglutination and multiplex PCR (Burall, Simpson,

114 \& Datta, 2011; Doumith, Buchrieser, Glaser, Jacquet, \& Martin, 2004) using modifications

115 described in Hellberg et al. (2013). The isolates were streaked to Tryptic Soy Agar (TSA) and

116 incubated overnight at $37^{\circ} \mathrm{C}$, then transferred to tryptic soy broth with $0.6 \%$ yeast extract

117 (TSBYE) and incubated overnight at $37^{\circ} \mathrm{C}$ to concentrations of $10^{8} \mathrm{CFU} / \mathrm{mL}$. Concentration

118 levels were determined by optical density (OD) measurement based on a logarithmic growth

119 curve (not shown) and verified by plate count on TSA. Bacterial cultures from the T1 and T4

120 isolates were grown separately. The cultures were then serially diluted to concentrations of $10^{6}$

$121 \mathrm{CFU} / \mathrm{mL}, 10^{4} \mathrm{CFU} / \mathrm{mL}, 10^{2} \mathrm{CFU} / \mathrm{mL}$, and $10^{\circ} \mathrm{CFU} / \mathrm{mL}$ in TSBYE. For T1 + T4 mixed culture

122 testing, equivalent amounts of the $\mathrm{T} 1$ and $\mathrm{T} 4$ cultures $\left(10^{8} \mathrm{CFU} / \mathrm{mL}\right)$ were combined prior to

123 carrying out serial dilutions.

1242.2 Microplate preparation

125 Polystyrene 96-well microtiter microplates separable into 8-well strips (Fisher Scientific,

126 Waltham, MA) were prepared for the concentration of $L$. monocytogenes according to a protocol

127 from Abcam (http://www.abcam.com/protocols/sandwich-elisa-protocol-1). Anti-Listeria

128 Polyclonal Antibody, HRP conjugate PA1-73129 (Invitrogen, Carlsbad, CA) was diluted to 1-10

$129 \mu \mathrm{g} / \mathrm{mL}$ in carbonate-bicarbonate buffer. The diluted antibodies were adhered to the inner surface

130 of the microplate by transferring $200 \mu \mathrm{L}$ of the solution to each of the wells. The plates were

131 then covered with plastic and held overnight $(8-16 \mathrm{~h})$ at $4{ }^{\circ} \mathrm{C}$. The following day, the plates were

132 rinsed with phosphate buffered saline solution (PBS), pH 7.4, blocked with a 5\% skim milk/PBS

133 solution, held at room temperature for $2 \mathrm{~h}$, and then rinsed a final time with PBS. Following this

134 process, the plates were used in microplate immunocapture, as described below, or stored at -

$13520^{\circ} \mathrm{C}$ until needed. 


\subsection{Optimization of microplate immunocapture}

The antibody-coated microplates prepared above were first tested with mixed cultures of L. monocytogenes Types 1 and 4 in TSBYE to optimize the method in the absence of a food matrix. The T1 + T4 cultures were prepared as described above to allow for concentrations of $10^{6} \mathrm{CFU} / \mathrm{mL}, 10^{4} \mathrm{CFU} / \mathrm{mL}, 10^{2} \mathrm{CFU} / \mathrm{mL}$, and $10^{0} \mathrm{CFU} / \mathrm{mL}$ (Singh, Batish, \& Grover, 2012). A

blank sample containing TSBYE was run alongside each set of experiments as a negative culture control. Microplate immunocapture was carried out in a biosafety hood and optimized for the number of fill cycles (1-4), hold times (15-60 min), antibody concentration (1-10 $\mu \mathrm{g} / \mathrm{mL})$, and use of a plate shaker (Bio Rad, Hercules, CA) at speeds of 10-120 RPM. For each fill cycle, 1.6 $\mathrm{mL}$ of each inoculated broth or control sample were transferred to 8 wells of the antibody-coated plate, resulting in $200 \mu \mathrm{L}$ of sample per well. The sample was then incubated at room temperature for a specific period of time (i.e., hold time) before being discarded and replaced in the next fill cycle. With each fill cycle, an additional $1.6 \mathrm{~mL}$ of the sample (200 $\mu \mathrm{L}$ per well) was added, resulting in a total volume of $6.4 \mathrm{~mL}$ per sample (800 $\mu \mathrm{L}$ per well) when 4 fill cycles were carried out.

Following microplate immunocapture, all 8 wells were scraped for each sample using a disposable sterile inoculating loop. The loop was then streaked onto polymyxin-acriflavine-LiClceftazidime-aesculin-mannitol (PALCAM) agar. Next, all 8 wells were scraped again for each sample using a second sterile inoculating loop. The second loop was then mixed with $100 \mu \mathrm{l}$ sterile water in a sterile Safe-lock microcentrifuge tube (Eppendorf, Hamburg, Germany) to release bacterial cells for DNA extraction, as described below. Positive culture controls were prepared using the $10^{8} \mathrm{CFU} / \mathrm{mL}$ broth sample, which was streaked directly to PALCAM or transferred to a microcentrifuge tube for DNA extraction using a sterile disposable loop. The 
159 PALCAM plates were incubated for $24 \pm 2 \mathrm{~h}$ at $37^{\circ} \mathrm{C}$. The plates were then examined for typical

160 L. monocytogenes growth, consisting of grey-green colonies with accompanied blackening of the

161 agar. Once optimal microplate immunocapture conditions were determined using the PALCAM

162 plates, the T1+T4 mixed culture as well as individual T1 and T4 cultures were tested in triplicate

163 using the optimized procedure (Table 1).

165 Table 1. Optimized conditions for microplate immunocapture (IC) for each matrix. Total

166 working time is given for microplate immunocapture combined with either selective plating on

167 PALCAM or detection with real-time PCR (qPCR) and includes sample preparation time.

\begin{tabular}{|c|c|c|c|c|c|c|}
\hline \multirow[t]{2}{*}{ Matrix } & \multirow{2}{*}{$\begin{array}{l}\text { \# of } \\
\text { fill } \\
\text { cycles }\end{array}$} & \multirow{2}{*}{$\begin{array}{l}\text { Cycle } \\
\text { hold } \\
\text { time } \\
\text { (min) }\end{array}$} & \multirow{2}{*}{$\begin{array}{l}L . \\
\text { monocytogenes } \\
\text { antibody } \\
\text { concentration } \\
(\mu \mathrm{g} / \mathrm{mL})\end{array}$} & \multirow{2}{*}{$\begin{array}{l}\text { Plate } \\
\text { shaker } \\
\text { speed } \\
\text { (RPM) }\end{array}$} & \multicolumn{2}{|c|}{ Total time required (h) } \\
\hline & & & & & IC + PALCAM & IC + qPCR \\
\hline TSBYE & 3 & 15 & 1 & 10 & $24.8 \pm 2$ & 3.1 \\
\hline $\begin{array}{l}\text { Skim } \\
\text { milk }\end{array}$ & 4 & 30 & 1 & 10 & $26 \pm 2$ & 4.3 \\
\hline $\begin{array}{l}\text { Queso } \\
\text { fresco } \\
\text { cheese }\end{array}$ & 4 & 45 & 1 & 10 & $27 \pm 2$ & 5.3 \\
\hline
\end{tabular}

168

170 The microplate immunocapture method was next optimized with skim milk (BD)

171 rehydrated with sterile deionized water and queso fresco cheese purchased at a local grocery

172 store. Prior to use in the inoculation trials, the cheese samples were first confirmed negative for

173 the presence of L. monocytogenes using the conventional culture method described in the BAM,

174 Chapter 10 (Hitchens et al., 2016). 
176 T1 + T4 cultures prepared as described above, resulting in final concentrations in the food

177 product of: $10^{6} \mathrm{CFU} / 25 \mathrm{~g}, 10^{4} \mathrm{CFU} / 25 \mathrm{~g}, 10^{2} \mathrm{CFU} / 25 \mathrm{~g}$, and $10^{0} \mathrm{CFU} / 25 \mathrm{~g}$. The samples were

178 then allowed to sit at room temperature under a biosafety hood for $2 \mathrm{~h}$ (Singh et al., 2012). An

179 un-inoculated sample was included in each trial as a negative control. The controls underwent

180 the same microplate immunocapture treatment as the inoculated samples. Each $25 \mathrm{~g}$ sample was

181 diluted with $225 \mathrm{~mL}$ TSBYE and then $1.6 \mathrm{~mL}$ of the mixture was transferred to 8 wells of the

182 antibody-coated plate, resulting in $200 \mu \mathrm{L}$ of sample per well. A broth sample containing $10^{8}$

$183 \mathrm{CFU} / \mathrm{mL}$ of L. monocytogenes T1 + T4 mixed culture was included in each trial as a positive

184 control. Microplate immunocapture with milk and cheese samples was carried out under a

185 biosafety hood at room temperature using an antibody concentration of $1 \mu \mathrm{g} / \mathrm{mL}$ and a plate

186 shaker speed of 10 RPM. The procedure was optimized for the number of fill cycles (2-4) and

187 hold times (15-60 min).

188 After microplate immunocapture, the wells of the microplate were scraped using an

189 inoculating loop and streaked onto PALCAM agar or transferred to sterile Safe-lock

190 microcentrifuge tubes containing $100 \mu \mathrm{l}$ sterile water for DNA extraction. The PALCAM plates

191 were incubated for $24 \pm 2 \mathrm{~h}$ at $37^{\circ} \mathrm{C}$. The plates were then examined for typical $L$.

192 monocytogenes growth. Once optimal microplate immunocapture conditions were determined 193 using PALCAM plates, the milk and cheese samples were inoculated with the T1 + T4 mixed

194 culture as well as individual T1 and T4 cultures and tested in triplicate using the optimized

195 protocol (Table 1). Each inoculated sample was also enriched in buffered Listeria enrichment

196 broth (BLEB) and plated in triplicate on PALCAM agar using the conventional culture method

197 described in the BAM, Chapter 10 (Hitchens et al., 2016). 
DNA extraction was carried out by incubating samples in a dry heat block at $100{ }^{\circ} \mathrm{C}$ for

$20010 \mathrm{~min}$, followed by cooling on ice and then centrifugation at 12,000 $\mathrm{x} \mathrm{g}$ for $5 \mathrm{~min}$ (Amagliani et

201 al., 2006). The supernatant was transferred to a fresh microcentrifuge tube and stored at $-20^{\circ} \mathrm{C}$

202 until use in real-time PCR. Real-time PCR was carried out in a Rotor-Gene Q thermocycler

203 (Qiagen, Hilden, Germany) using the L. monocytogenes-specific primers and probes detailed in 204 FDA (2015). Each reaction tube contained 0.5 lyophilized OmniMix-HS beads (Takara Bio,

205 Dalian, China), $0.625 \mu \mathrm{L}$ each of $10 \mu \mathrm{M}$ forward and reverse primers $(0.25 \mu \mathrm{M}$ final

206 concentration), $0.25 \mu \mathrm{L}$ of $10 \mu \mathrm{M}$ probe ( $0.1 \mu \mathrm{M}$ final concentration), $5 \mu \mathrm{L}$ extracted template

207 DNA, and sterile distilled water to bring the final reaction volume to $25 \mu \mathrm{L}$ per sample. PCR

208 cycling conditions started with an initial activation of $94{ }^{\circ} \mathrm{C}$ for $60 \mathrm{~s}$, followed by 45 cycles of

$20994^{\circ} \mathrm{C}$ for $10 \mathrm{~s}$ and $60{ }^{\circ} \mathrm{C}$ for $45 \mathrm{~s}$. Each real-time PCR run included a negative non-template

210 control and three positive DNA controls originating from the bacterial culture: undiluted

211 bacterial DNA and two tenfold serial dilutions of bacterial DNA (1:10 and 1:100). The results

212 were analyzed using Rotor-Gene Q software and reported on a qualitative basis, where the

213 presence of a cycle of quantitation $(\mathrm{Cq})$ value indicated a positive sample.

\section{3. Results and discussion}

\section{3.1 Microplate immunocapture with broth samples}

216 The conditions for microplate immunocapture were successfully optimized using the

217 mixed T1 + T4 culture of Listeria monocytogenes in TSBYE combined with plating on

218 PALCAM agar. During optimization trials, it was found that the bacteria could be detected at a

219 starting inoculation of $10^{0} \mathrm{CFU} / \mathrm{mL}$ when 4 fill cycles were used with hold times of $1 \mathrm{~h}$ each, 220 combined with the lowest antibody concentration tested $(1 \mu \mathrm{g} / \mathrm{mL})$. However, reducing either the 
221 hold time or the number of fill cycles resulted in a reduction in the sensitivity of the method,

222 with detection starting at $10^{2} \mathrm{CFU} / \mathrm{mL}$, even when the antibody concentration was increased to

$22310 \mu \mathrm{g} / \mathrm{mL}$. Interestingly, use of the plate shaker at speeds of 80-120 RPM did not reduce the

224 number of fill cycles or the hold time required for detection at $10^{\circ} \mathrm{CFU} / \mathrm{mL}$. On the other hand,

225 when the speed was reduced to $10-40 \mathrm{RPM}$, detection at $10^{0} \mathrm{CFU} / \mathrm{mL}$ was possible using only 3

226 fill cycles and hold times of 15 min each, combined with an antibody concentration of $1 \mu \mathrm{g} / \mathrm{mL}$.

227 This reduced the overall time required for concentration down to $75 \mathrm{~min}$, as compared to $4 \mathrm{~h}$ in

228 the absence of the plate shaker. Table 1 shows the optimal conditions determined for microplate

229 immunocapture with broth.

230 Table 2 shows the results of triplicate testing of broth samples using the optimized

231 conditions with L. monocytogenes T1, T4, and the mixed T1 + T4 culture. Overall, these

232 conditions allowed for detection of the strains (individually or mixed) at a level of $10^{0} \mathrm{CFU} / \mathrm{mL}$

233 when combined with selective plating on PALCAM or detection with real-time PCR. The results

234 for all positive and negative controls were as expected. Microplate immunocapture combined

235 with selective plating showed a slightly higher overall detection rate, with 35/36 detections

236 (97.2\%) on PALCAM across all inoculation levels compared to 33/36 detections (91.7\%) with

237 real-time PCR. Differences in the results occurred only at the lowest inoculation level $\left(10^{0}\right.$

$238 \mathrm{CFU} / \mathrm{mL}$ ), with 8/9 detections (88.9\%) on PALCAM and 6/9 detections (66.7\%) with real-time

239 PCR. Microplate immunocapture combined with selective plating or real-time PCR allowed for

240 positive detections in $100 \%$ of replicates tested at inoculation levels of $10^{2}$ to $10^{6} \mathrm{CFU} / \mathrm{mL}$. Real-

241 time PCR was less consistent in detecting $L$. monocytogenes at the lowest inoculation level $\left(10^{0}\right.$

$242 \mathrm{CFU} / \mathrm{mL}$ ), with detection in only 2 of the 3 replicates for the individual and mixed cultures. On

243 the other hand, plating on PALCAM agar at the lowest inoculation level allowed for consistent 
Table 2. Rates of L. monocytogenes detection for the immunocapture (IC) method combined with selective plating on PALCAM or real-time PCR (qPCR) at a range of cell concentrations. The results of detection in food samples using conventional culture with no IC are included for comparison.

\begin{tabular}{|c|c|c|c|c|c|c|}
\hline \multirow[t]{3}{*}{ Method } & \multirow{3}{*}{$\begin{array}{l}\text { L. monocytogenes } \\
\text { type }\end{array}$} & \multicolumn{5}{|c|}{ Rate of detection (no. positive samples/total no. samples) } \\
\hline & & Broth $(\mathrm{CFU} / \mathrm{mL})$ & Milk (CFU/25 mL) & \multicolumn{3}{|c|}{ Cheese (CFU/25 g) } \\
\hline & & $\begin{array}{llll}10^{0} & 10^{2} & 10^{4} & 10^{6} \\
\end{array}$ & $\begin{array}{llll}10^{0} & 10^{2} & 10^{4} & 10^{6} \\
\end{array}$ & $10^{0}$ & $10^{2}$ & $10^{4} \quad 10^{6}$ \\
\hline \multirow[t]{4}{*}{ IC + PALCAM } & $\mathrm{T} 1$ & $\begin{array}{llll}3 / 3 & 3 / 3 & 3 / 3 & 3 / 3\end{array}$ & $\begin{array}{llll}0 / 3 & 2 / 3 & 3 / 3 & 3 / 3\end{array}$ & $0 / 3$ & $0 / 3$ & $3 / 3 \quad 3 / 3$ \\
\hline & $\mathrm{T} 4$ & $2 / 3 \quad 3 / 3 \quad 3 / 3 \quad 3 / 3$ & $\begin{array}{llll}0 / 3 & 3 / 3 & 3 / 3 & 3 / 3\end{array}$ & $0 / 3$ & $0 / 3$ & $3 / 3 \quad 3 / 3$ \\
\hline & $\mathrm{T} 1+\mathrm{T} 4$ & $\begin{array}{llll}3 / 3 & 3 / 3 & 3 / 3 & 3 / 3\end{array}$ & $\begin{array}{llll}0 / 3 & 3 / 3 & 3 / 3 & 3 / 3\end{array}$ & $0 / 3$ & $0 / 3$ & $3 / 3 \quad 3 / 3$ \\
\hline & Total \% & $88.9 \quad 100 \quad 100100$ & $88.9 \quad 100 \quad 100$ & 0 & 0 & 100100 \\
\hline \multirow[t]{4}{*}{ IC + qPCR } & $\mathrm{T} 1$ & $2 / 3 \quad 3 / 3 \quad 3 / 3 \quad 3 / 3$ & $3 / 3 \quad 3 / 3 \quad 3 / 3 \quad 3 / 3$ & $3 / 3$ & $3 / 3$ & $3 / 3 \quad 3 / 3$ \\
\hline & $\mathrm{T} 4$ & $2 / 3 \quad 3 / 3 \quad 3 / 3 \quad 3 / 3$ & $\begin{array}{llll}3 / 3 & 3 / 3 & 3 / 3 & 3 / 3\end{array}$ & $3 / 3$ & $3 / 3$ & $3 / 3 \quad 3 / 3$ \\
\hline & $\mathrm{T} 1+\mathrm{T} 4$ & $2 / 3 \quad 3 / 3 \quad 3 / 3 \quad 3 / 3$ & $2 / 3 \quad 2 / 3 \quad 3 / 3 \quad 3 / 3$ & $2 / 3$ & $3 / 3$ & $3 / 3 \quad 3 / 3$ \\
\hline & Total \% & $\begin{array}{llll}66.7 & 100 & 100 & 100\end{array}$ & $\begin{array}{llll}88.9 & 88.9 & 100 & 100\end{array}$ & 88.9 & 100 & 100100 \\
\hline \multirow{4}{*}{$\begin{array}{l}\text { Conventional } \\
\text { culture }\end{array}$} & $\mathrm{T} 1$ & NA & $\begin{array}{llll}3 / 3 & 3 / 3 & 3 / 3 & 3 / 3\end{array}$ & $3 / 3$ & $3 / 3$ & $3 / 3 \quad 3 / 3$ \\
\hline & $\mathrm{T} 4$ & NA & $\begin{array}{llll}3 / 3 & 3 / 3 & 3 / 3 & 3 / 3\end{array}$ & $3 / 3$ & $3 / 3$ & $3 / 3 \quad 3 / 3$ \\
\hline & $\mathrm{T} 1+\mathrm{T} 4$ & NA & $\begin{array}{llll}3 / 3 & 3 / 3 & 3 / 3 & 3 / 3\end{array}$ & $3 / 3$ & $3 / 3$ & $3 / 3 \quad 3 / 3$ \\
\hline & Total \% & NA & $\begin{array}{lll}100 & 100 & 100\end{array}$ & 100 & 100 & 100100 \\
\hline
\end{tabular}


244 detection in all samples except one of the three T4 replicates. Combining the time for microplate

245 immunocapture concentration with traditional plating, positive results can be determined in 24.8

$246 \mathrm{~h} \pm 2 \mathrm{~h}$ while combining the concentration method with real-time PCR can allow for a positive

247 detection in $3.1 \mathrm{~h}$ (Table 1). These times are substantially less compared to the traditional

248 enrichment-based method, which takes at least $48 \pm 4 \mathrm{~h}$ for isolation of L. monocytogenes.3.2

249 Microplate immunocapture with skim milk samples

250 The optimal conditions determined for the broth samples yielded no detection at the

251 lowest inoculation levels $\left(10^{0}-10^{2} \mathrm{CFU} / 25 \mathrm{~mL}\right)$ for skim milk inoculated with the $\mathrm{T} 1+\mathrm{T} 4$

252 mixed culture and plated on PALCAM agar. Therefore, further optimization was carried out for

253 microplate immunocapture of L. monocytogenes in skim milk within the pre-determined range of

254 parameters. This resulted in detection with PALCAM at a starting inoculation of $10^{2} \mathrm{CFU} / 25 \mathrm{~mL}$

255 using the optimized run conditions (Table 1).

256 Table 2 shows the results of triplicate testing of skim milk samples using the optimized

257 conditions with L. monocytogenes T1, T4, and the mixed T1 + T4 culture. The results for all

258 positive and negative controls were as expected. Overall, these conditions allowed for detection

259 of the strains (individually or mixed) at a level of $10^{2} \mathrm{CFU} / 25 \mathrm{~mL}$ when combined with selective

260 plating on PALCAM and at a level of $10^{\circ} \mathrm{CFU} / 25 \mathrm{~mL}$ when using real-time PCR. Microplate

261 immunocapture combined with real-time PCR showed a greater overall detection rate, with

$26234 / 36$ detections (94.4\%) across all inoculation levels, as compared to 26/36 detections (72.2\%)

263 using PALCAM. Similar to the broth results, differences between the two detection methods

264 occurred only at the lower inoculation levels. At the $10^{\circ} \mathrm{CFU} / 25 \mathrm{~mL}$ and $10^{2} \mathrm{CFU} / 25 \mathrm{~mL}$ levels,

265 16/18 detections (88.9\%) were observed using real-time PCR with only 8/18 detections (44.4\%)

266 using PALCAM. However, both of these rates were lower than that obtained using the 
267 conventional culture method, which showed $100 \%$ positive detections across all inoculation

268 levels. A previous study on V. cholerae, S. enterica Typhi, and S. flexneri in meat and seafood

269 samples reported overall detection rates of 56.0-65.3\% for microplate immunocapture combined

270 with selective plating and rates of $62.7-69.3 \%$ for microplate immunocapture combined with

271 PCR (Fakruddin et al., 2017). These rates are based on the combined detections across all

272 inoculation levels $\left(10^{1} \mathrm{CFU} / \mathrm{g}\right.$ to $\left.10^{5} \mathrm{CFU} / \mathrm{g}\right)$ for each pathogen tested. Similar to the current

273 study, Yang, Qu, Wimbrow, Jiang, and Sun (2007) reported detection of L. monocytogenes in

274 milk samples at the lowest inoculation level tested $\left(10^{2} \mathrm{CFU} / 0.5 \mathrm{~mL}\right)$ when nanoparticle-based

275 immunomagnetic separation was combined with real-time PCR.

276 As shown in Table 2, the use of microplate immunocapture combined with selective

277 plating or real-time PCR allowed for positive detections in 100\% of replicates tested at

278 inoculation levels of $10^{4}$ to $10^{6} \mathrm{CFU} / 25 \mathrm{~mL}$. At both the $10^{0}$ and $10^{2} \mathrm{CFU} / 25 \mathrm{~mL}$ levels, one of

279 the three replicates of $L$. monocytogenes T1 + T4 was negative with PCR, however all other

280 triplicate runs maintained $100 \%$ positive results. By comparison, a previous study utilizing

281 immunomagnetic separation combined with PCR allowed for detection of $5 \mathrm{CFU} / \mathrm{mL} L$.

282 monocytogenes in $50 \%$ of milk samples and detection of $10 \mathrm{CFU} / \mathrm{mL}$ in $100 \%$ of milk samples

283 (Amagliani et al., 2006). On the other hand, microplate immunocapture combined with

284 PALCAM was unable to detect $L$. monocytogenes in any of the replicates tested at the lowest 285 inoculation level.

286 As shown in Table 1, use of microplate immunocapture combined with selective plating

287 can shorten the time for isolation of $L$. monocytogenes in milk to $26 \pm 2 \mathrm{~h}$, while the use of

288 microplate immunocapture combined with real-time PCR can reduce the time to detection to 4.0

289 h. It is possible that the sensitivity of the method could be improved by increasing the number of 
290 fill cycles or by combining the immunocapture assay with a short pre-enrichment period, while

291 still allowing for a significantly shorter detection time than conventional methods.

2923.3 Microplate immunocapture with queso fresco samples

293 Similar to the decrease in sensitivity observed for selective plating when moving from

294 TSBYE to skim milk samples, the results with queso fresco cheese showed decreased sensitivity

295 as compared to those with skim milk. When the optimized microplate immunocapture

296 parameters for skim milk were applied to queso fresco, detection of $L$. monocytogenes with

297 selective plating was only possible at the highest inoculation level $\left(10^{6} \mathrm{CFU} / 25 \mathrm{~g}\right)$. Therefore,

298 further optimization was carried out with queso fresco samples to improve the sensitivity of the

299 method. The optimized conditions allowed for detection of $L$. monocytogenes with selective

300 plating starting at an inoculation level of $10^{4} \mathrm{CFU} / 25 \mathrm{~g}$ (Table 1 ).

301 Table 2 shows the results of triplicate testing of queso fresco cheese samples using the

302 optimized conditions with L. monocytogenes T1, T4, and the mixed T1 + T4 culture. All positive

303 and negative control results were as expected. Overall, these conditions allowed for detection of

304 the strains (individually or mixed) at a level of $10^{4} \mathrm{CFU} / 25 \mathrm{~g}$ when combined with selective

305 plating on PALCAM and at a level of $10^{\circ} \mathrm{CFU} / \mathrm{mL}$ when using real-time PCR. As with the milk

306 samples, microplate immunocapture combined with real-time PCR showed a higher overall

307 detection rate, with 35/36 detections (97.2\%) across all inoculation levels, as compared to 18/36

308 detections (50.0\%) with PALCAM. The differences in detection rates occurred at the lowest

309 inoculation levels $\left(10^{\circ} \mathrm{CFU} / 25 \mathrm{~g}\right.$ and $\left.10^{2} \mathrm{CFU} / 25 \mathrm{~g}\right)$, with $17 / 18$ detections (94.4\%) for real-time

310 PCR and 0/18 detections (0\%) for PALCAM. In contrast, the conventional culture method

311 showed $100 \%$ positive detection across all inoculation levels. 
313 for the cheese samples were higher than those reported by Fakruddin et al. (2017) for $V$.

314 cholerae, S. enterica Typhi, and S. flexneri in meat and seafood samples (62.7-69.3\%) inoculated

315 at levels of $10^{1} \mathrm{CFU} / \mathrm{g}$ to $10^{5} \mathrm{CFU} / \mathrm{g}$. However, the rate of detection determined in the current

316 study (50\%) using microplate immunocapture combined with selective plating for the cheese

317 samples was slightly lower than the rates reported by Fakruddin et al. (2017) for meat and

318 seafood samples (56.0-65.3\%). Similar to the results obtained for microplate immunocapture

319 combined with real-time PCR in the current study, Mao et al. (2016) reported detection of $L$.

320 monocytogenes in lettuce at the lowest inoculation level tested (10 $\left.{ }^{1} \mathrm{CFU} / \mathrm{g}\right)$ using a combination

321 of immunomagnetic separation and multiplex PCR. Likewise, Duodu, Mehmeti, Holst-Jensen,

322 and Loncarevic (2009) used a combination of filtration, immunomagnetic separation, and real-

323 time PCR to detect L. monocytogenes in smoked salmon at levels of $10^{1} \mathrm{CFU} / \mathrm{g}$.

As shown in Table 2, the use of microplate immunocapture combined with selective

325 plating or real-time PCR allowed for positive detections in 100\% of replicates tested at

326 inoculation levels of $10^{4}$ to $10^{6} \mathrm{CFU} / 25 \mathrm{~g}$. One of the three replicates of the T1+T4 mixed culture

327 at the $10^{0} \mathrm{CFU} / 25 \mathrm{~g}$ inoculation level was not detected by real-time PCR, but all other samples

328 and replicates were detected by this method. Overall, the sensitivity in detecting $L$.

329 monocytogenes decreases when moving from broth to skim milk and then to cheese for detection 330 with selective plating but not for real-time PCR.

331 As shown in Table 1, use of microplate immunocapture combined with selective plating

332 can reduce the time for isolation of $L$. monocytogenes in cheese samples to $27 \pm 2 \mathrm{~h}$, while use of

333 microplate immunocapture combined with real-time PCR can allow for detection of positive 
334 samples within $4.5 \mathrm{~h}$. As with the milk samples, the sensitivity of the method may be improved

335 by increasing the number of fill cycles or by adding a short pre-enrichment period.

Microplate immunocapture coupled with real-time PCR or selective plating was capable

338 of detecting L. monocytogenes isolates in $100 \%$ of food samples inoculated at $10^{4}$ and $10^{6}$

339 CFU/25 g. However, these methods did not perform as well as conventional culture for the

340 detection of L. monocytogenes at lower inoculation levels $\left(10^{0}\right.$ and $\left.10^{2} \mathrm{CFU} / 25 \mathrm{~g}\right)$. At these

341 levels, microplate immunocapture showed a detection rate of 91.7\% when coupled with real-time

342 PCR and 22.2\% when coupled with selective plating on PALCAM. In comparison, the

343 conventional culture method showed consistent levels of sensitivity when moving from skim

344 milk to cheese and had a 100\% detection rate across all inoculation levels. These results are in

345 agreement with the limit of detection reported in the BAM for L. monocytogenes, at $<1$ CFU per

346 analytical unit (Hitchens et al., 2016).

347 Microplate immunocapture combined with selective plating allowed for detection of $L$.

348 monocytogenes in cheese samples down to levels of $10^{4} \mathrm{CFU} / 25 \mathrm{~g}$. This detection limit can be

349 explained mathematically, even when not considering incubation time following inoculation or

350 hold times in the microplate. Inoculation started at 10,000 cells (10 $\mathrm{CFU} / 25 \mathrm{~g})$ and $225 \mathrm{~mL}$ of

351 TSBYE was added, resulting in a concentration of 10,000 cells in $250 \mathrm{~mL}$. This equates to 40

352 cells for every $\mathrm{mL}$ (40 CFU/mL). Considering that 4 fill cycles were used with the cheese

353 samples (total volume of $6.4 \mathrm{~mL}$ ), it is likely that detection would be possible with selective

354 plating.

355 Detection of L. monocytogenes was possible in the majority (89\%) of milk samples

356 inoculated at $10^{2} \mathrm{CFU} / 25 \mathrm{~g}$. Theoretically, after the addition of $225 \mathrm{~mL}$ TSBYE, this inoculation 
357 level should have contained 100 cells in $250 \mathrm{~mL}(0.4 \mathrm{CFU} / \mathrm{mL})$. The use of 4 fill cycles at 1.6

$358 \mathrm{~mL}$ each would have resulted in exposure of the microplate wells to 2.56 cells. However, this

359 does not take into account the $2 \mathrm{~h}$ sample incubation following inoculation or the microplate hold

360 times in TSBYE broth. The hold times for skim milk were $30 \mathrm{~min}$ for a total of $2 \mathrm{~h}$ after all 4 fill

361 cycles were completed. During this time, the bacteria would have likely continued to grow both

362 within the microplate wells and in the bag containing the inoculated sample. Given the

363 generation time for $L$. monocytogenes is approximately $1-2 \mathrm{~h}$ in growth medium or skim milk at

364 room temperature, the final concentration of cells in the sample could have reached 1.6-6.4

365 CFU/mL (Katoh, 1989; Petran \& Zottola, 1989; Rosenow \& Marth, 1987). The cheese samples

366 were not capable of positive results at this level most likely due to food matrix interference. Even

367 considering hold times and multiple fill cycles, small particles of cheese were seen in the

368 microplate and were unavoidable, making capturing such low concentrations of $L$.

369 monocytogenes cells difficult.

370 Microplate immunocapture combined with real-time PCR showed detection of $L$.

371 monocytogenes down to $10^{0} \mathrm{CFU} / 25 \mathrm{~g}$ in food samples. Theoretically, after the addition of 225

372 mL TSBYE, this inoculation level would be expected to contain 1 cell in $250 \mathrm{~mL}$ (0.004

$373 \mathrm{CFU} / \mathrm{mL}$ ). The use of 4 fill cycles at $1.6 \mathrm{~mL}$ each would have resulted in exposure of the

374 microplate wells to 0.026 cells. However, this does not take into account the $2 \mathrm{~h}$ incubation

375 following inoculation or the hold times in TSBYE broth. Hold times were 30 min for skim milk

376 and $45 \mathrm{~min}$ for cheese, resulting in a total of 2-3 $\mathrm{h}$ after all fill cycles were completed. Based on

377 the generation times stated above, the concentration of L. monocytogenes in samples could have

378 reached $1.6 \times 10^{-2} \mathrm{CFU} / \mathrm{mL}$ to $1.3 \times 10^{-1} \mathrm{CFU} / \mathrm{mL}$ after the final hold time. Although these levels

379 were not detectable with selective plating, real-time PCR does not require viable or even 
complete cells for detection, but rather it shows the presence of specific DNA fragments from

381 lysed cells.

382 Though non-viable cells of L. monocytogenes are not considered pathogenic, detecting

383 them using microplate immunocapture coupled with real-time PCR may prove beneficial in

384 showing the presence of Listeria in a statistical sample batch, which is exceptionally important in

385 foods eaten raw. Thus, the present method may have greater potential beyond viable cell

386 detection and is yet another data point on the validity of using microplate immunocapture along

387 with the studies conducted by Fakruddin et al. (2017), Arbault et al. (2014), and Molloy et al.

388 (1995).

\section{4. Conclusions}

390 Overall, this study showed that recovery of L. monocytogenes at cell levels of $10^{0}$

391 CFU/25 g could be achieved at much higher rates in milk and cheese samples using microplate

392 immunocapture combined with real-time PCR detection as compared to microplate

393 immunocapture combined with selective plating. The overall recovery rates for $L$.

394 monocytogenes in these matrices (milk and cheese) at cell populations of $10^{0}, 10^{2}$, and $10^{4}$

395 CFU/25 g using microplate immunocapture with real-time PCR detection were 88.9\%, 94.4\%,

396 and 100\%, respectively. Recovery using microplate immunocapture combined with selective

397 plating was comparatively lower, at $0 \%, 44.4 \%$, and $100 \%$, respectively. The complexity of the

398 matrix impacted L. monocytogenes recoveries using selective plating, with procedures becoming

399 increasingly less effective as the food matrix became more complex. However, this trend was not

400 observed with real-time PCR, which actually showed the greatest detection rates for the most

401 complex matrix (cheese). Although microplate immunocapture combined with real-time PCR

402 shows promise as a rapid means for concentrating and detecting L. monocytogenes, the recovery 
403 rate at low initial cell populations was not equivalent to that obtained with the conventional

404 culture method. Therefore, future studies should investigate the incorporation of a short

405 enrichment period and/or additional optimization of the microplate immunocapture method.

406 Additionally, the optimized method should undergo inclusivity testing with a panel of $L$.

407 monocytogenes isolates as well as testing to ensure that the presence of other Listeria spp. does

408 not interfere with the ability of the assay to capture L. monocytogenes.

\section{Acknowledgements}

410 This work was supported by internal funding from Chapman University, Schmid College

411 of Science and Technology. The funding source was not involved in the study design; collection,

412 analysis and interpretation of the data; in the writing of the report; or in the decision to submit

413 the article for publication. The authors would like to thank Rachel Isaacs for assisting with

414 laboratory work. Additional support and materials were provided by Denise Foley, Ph.D.,

415 Santiago Canyon College, as well as Karylin Gonzalez and the Food Microbiological Laboratory

416 team. The authors declare no conflicts of interest.

\section{$417 \quad$ References}

418 1. Amagliani, G., Omiccioli, E., del Campo, A., Bruce, I. J., Brandi, G., \& Magnani, M.

419 (2006). Development of a magnetic capture hybridization-PCR assay for Listeria

420 monocytogenes direct detection in milk samples. Journal of Applied Microbiology,

$421 \quad 100(2), 375-383$.

$422 \quad$ 2. Arbault, P., Desroche, N., \& Larose, D. (2014). Methods for immunocapture and

423 concentration of bacteria in a sample. EP Patent 14710330.

424 3. Arbault, P., Larose, D., Desroche, N., \& Nexidia, J. G. (2014). Microplate

425 immunocapture (IMC): A new solution for the isolation/concentration of Escherichia coli 
427 Protection Annual Meeting, Indianapolis, IN.

428 4. Burall, L. S., Simpson, A. C., \& Datta, A. R. (2011). Evaluation of a serotyping scheme 429 using a combination of an antibody-based serogrouping method and a multiplex PCR 430 assay for identifying the major serotypes of Listeria monocytogenes. Journal of Food $431 \quad$ Protection, 74(3), 403-409.

$432 \quad 5 . \quad$ CDC. Listeria outbreaks. Centers for Disease Control and Prevention. (2017). 433 https://www.cdc.gov/listeria/outbreaks/ Accessed 8 January 2018.

434 6. Chen, Q., Li, Y., Tao, T., Bie, X., Lu, F., \& Lu, Z. (2017). Development and application 435 of a sensitive, rapid, and reliable immunomagnetic separation-PCR detection method for 436 Cronobacter spp. J Dairy Sci, 100(2), 961-969.

437 7. Doumith, M., Buchrieser, C., Glaser, P., Jacquet, C., \& Martin, P. (2004). Differentiation 438 of the major Listeria monocytogenes serovars by multiplex PCR. Journal of Clinical 439 Microbiology, 42(8), 3819-3822.

440 8. Duodu, S., Mehmeti, I., Holst-Jensen, A., \& Loncarevic, S. (2009). Improved sample 441 preparation for real-time PCR detection of Listeria monocytogenes in hot-smoked salmon 442 using filtering and immunomagnetic separation techniques. Food Analytical Methods, $443 \quad$ 2(1), 23-29.

444 9. Fakruddin, M., Hossain, M. N., \& Ahmed, M. M. (2017). Evaluation of microplate 445 immunocapture method for detection of Vibrio cholerae, Salmonella Typhi and Shigella $446 \quad$ flexneri from food. BMC Microbiol, 17(1), 189. 
447

448

449

450

451

452

453

454

455

456

457

458

459

460

461

462

463

464

465

466

467

468

10. FDA. (2012). Bad Bug Book, Foodborne Pathogenic Microorganisms and Natural Toxins (K. A. Lampel, S. Al-Khaldi, \& S. M. Cahill Eds. 2nd ed.): Food and Drug Administration.

11. FDA. (2015). BAM Protocol: Simultaneous confirmation of Listeria species and $L$. monocytogenes isolates by real-time PCR. Bacteriological Analytical Manual. Food and Drug Administration, Silver Spring, MD.

12. FDA. All Recalls. (2018). http://www.fda.gov/AJAX/All/default.htm Accessed 12 February 2018.

13. Gould, H. L., Mungai, E., \& Behravesh, C. B. (2014). Outbreaks attributed to cheese: Differences between outbreaks caused by unpasteurized and pasteurized dairy products, United States, 1998-2011. Foodborne Pathog Dis, 11(7), 545-551.

14. Hellberg, R. S., Martin, K. G., Keys, A. L., Haney, C. J., Shen, Y., \& Smiley, R. D. (2013). 16S rRNA partial gene sequencing for the differentiation and molecular subtyping of Listeria species. Food Microbiology, 36, 231-240.

15. Hitchens, A. D., Jinneman, K., \& Chen, Y. (2016). Detection and enumeration of Listeria monocytogenes in foods. Bacteriological Analytical Manual. Food and Drug Administration, Silver Spring, MD.

16. Katoh, H. (1989). Listeria monocytogenes: Determination of mean generation time for Listeria monocytogenes. Japanese Journal of Food Microbiology, 6(2), 135-138.

17. Law, J. W.-F., Ab Mutalib, N.-S., Chan, K.-G., \& Lee, L.-H. (2015). Rapid methods for the detection of foodborne bacterial pathogens: principles, applications, advantages and limitations. Front Microbiol, 5(Article 770). 
18. Ma, K., Deng, Y., Bai, Y., Xu, D., Chen, E., Wu, H., . . Gao, L. (2014). Rapid and simultaneous detection of Salmonella, Shigella, and Staphylococcus aureus in fresh pork using a multiplex real-time PCR assay based on immunomagnetic separation. Food Control, 42, 87-93.

19. Mao, Y., Huang, X., Xiong, S., Xu, H., Aguilar, Z. P., \& Xiong, Y. (2016). Large-volume immunomagnetic separation combined with multiplex PCR assay for simultaneous detection of Listeria monocytogenes and Listeria ivanovii in lettuce. Food Control, 59, 601-608.

20. Molloy, P., Brydon, L., Porter, A. J., \& Harris, W. J. (1995). Separation and concentration of bacteria with immobilized antibody fragments. J Appl Bacteriol, 78(4), 359-365.

21. Moreno-Enriquez, R. I., Garcia-Galaz, A., Acedo-Felix, E., Gonzalez-Rios, H., Call, J. E., Luchansky, J. B., \& Diaz-Cinco, M. E. (2007). Prevalence, types, and geographical distribution of Listeria monocytogenes from a survey of retail queso fresco and associated cheese processing plants and dairy farms in Sonora, Mexico. J Food Prot, 70(11), 2596-2601.

22. Petran, R. L., \& Zottola, E. A. (1989). A Study of Factors Affecting Growth and Recovery of Listeria monocytogenes Scott A. Journal of Food Science, 54(2), 458-460.

23. Rosenow, E. M., \& Marth, E. H. (1987). Growth of Listeria monocytogenes in skim, whole and chocolate milk, and in whipping cream during incubation at 4, 8, 13, 21 and $35^{\circ} \mathrm{C}$. Journal of Food Protection, 50(6), 452-459. 
490 24. Scallan, E., Hoekstra, R. M., Angulo, F. J., Tauxe, R. V., Widdowson, M. A., Roy, S. L., 491 . . G Griffin, P. M. (2011). Foodborne illness acquired in the United States--major 492 pathogens. Emerg. Infect. Dis., 17(1), 7-15.

493 25. Singh, J., Batish, V. K., \& Grover, S. (2012). Simultaneous detection of Listeria 494 monocytogenes and Salmonella spp. in dairy products using real time PCR-melt curve 495 analysis. J Food Sci Technol, 49(2), 234-239.

496 26. Stevens, K. A., \& Jaykus, L.-A. (2004). Bacterial separation and concentration from 497 complex sample matrices: A review. Crit Rev Microbiol, 30(1), 7-24.

498 27. Yang, H., Qu, L., Wimbrow, A. N., Jiang, X., \& Sun, Y. (2007). Rapid detection of 499 Listeria monocytogenes by nanoparticle-based immunomagnetic separation and real-time PCR. International Journal of Food Microbiology, 118(2), 132-138.

501 28. Zhao, X., Lin, C. W., Wang, J., \& Oh, D. H. (2014). Advances in rapid detection methods 502 for foodborne pathogens. J Microbiol Biotechnol, 24(3), 297-312. 